\title{
Proses Kreasi Seorang Desainer Grafis (Studi Kasus : Stefan Sagmeister)
}

\author{
Rini Maulina \\ Program Studi Desain Komunikasi Visual, Universitas Komputer Indonesia
}

\begin{abstract}
Abstrak.Proses kreasi merupakan tahapan penting bagi seorang desainer grafis dalam pencapaian karya. Proses kreasi yang dialami oleh seniman, desainer grafis atau pelaku kreatif biasanya tidak disadari oleh pelaku kreatif itu sendiri. Dalam keilmuan psikologi khususnya psikologi seni proses kreasi dapat dikategorikan berdasarkan tipe-tipe dari cara berfikir atau cara bagaimana pelaku kreatif tersebut memecahkan masalah yang dihadapi ketika bekerja kreatif. Proses kreatif seorang kreatif dipengaruhi oleh beberapa factor yang ditelaah lewat psikologi personal dari pelaku kreatif.
\end{abstract}

Stefan Sagmeister adalah seorang desainer grafis sekaligus seniman yang memiliki beberapa tipe proses kreasi. Beliau adalah seorang kreatif yang pola berkreasinya dapat dijadikan sebagai pembelajaran. Penilitian ini merupakan tinjauan dari Stefan Sagmeister, mengenai proses kreasi seorang desainer grafis sekaligus seniman kontemporer yang menciptakan karya desain dengan melewati batas-batas desain dan seni. Karya-karya Stefan Sagmeister menggambarkan cirri-ciri kontemporer. Tinjauan ini dilakukan untuk mengetahui dan mempelajari apakah proses kreasinya dipengaruhi oleh perkembangan dunia seni rupa dan desain secara umum, dimana saat ini merupakan era kontemporer yang mengusung eksperimental, eklektik, simbolik sekaligus spiritual yang mempengaruhi pola berfikir dan berkarya di segala bidang khususnya bidang desain grafis.

Kata kunci: Proses Kreasi, Desainer Grafis

\section{PENDAHULUAN}

Bidang Desain Grafis dalam tubuh modernisme merupakan low art, namun pada masa postmodern Andy Warhol menggunakan bahasa grafis sebagai media karya seninya, sehingga muncul gerakan seni pop art. Hal ini menandakan mulai cairnya batasan seni dan desain, dimana banyak sekali seniman yang menggunakan bahasa desain grafis sebagai karya seni dan desainer grafis yang menggunakan bahasa seni sebagai karya desainnya. Fenomena the end of art (the end of modernisme) yang terjadi dalam dunia seni melahirkan prinsip anything goes, seperti yang telah dilakukan seniman dalam gerakan postmodern. Hal 
tersebut mempengaruhi wilayah desain, tidak terlepas dari tendensi kontemporer dimana karya desain dibuat semenarik mungkin sebagai salah satu perwujudan dari kapitalis lanjut, desain dalam masa kontemporer memiliki orientasi yang sama dengan seni; eksperimental, sublimasi, unik, pembaharuan, intens terhadap persoalan moral, intuitif, imajinatif, pluralisme, eklektik, ironi, humor, parodi, hibrid, simbolik, menjadi wilayah penting dari desain.

Stefan Sagmeister merupakan salah seorang desainer grafis yang menggambarkan fenomena diatas. Stefan Sagmeister adalah seorang desainer grafis dari Austria, ia memiliki perusahaan Sagmeister. Inc berupa konsultan desain di New York, Amerika. Ia seorang desainer grafis paling inovatif dan berpengaruh saat ini. Konsepsinya dan aplikasi desain grafisnya berjalan diatas dan diluar paham tradisional, (pengertian tentang praktek seni modern), hal tersebut membawanya kebidang seni performatif dan konseptual, lukisan bahkan patung. Stefan Sagmeister dipilih sebagai objek analisa karena ia memiliki proses kreatifitas yang sangat menarik dan sangat berbeda dari desainer grafis pada umumnya. kreatifitas dan gagasan yang ia hasilkan sangat orisinil, Ia memiliki jadwal berkarya yang sangat disiplin, bekerja sama dengan sebuah tim untuk mewujudkan idenya, dengan penggunaan multi medium pada karya-karya desainnya, desainer grafis sekaligus seniman yang aktif menggelar pameran di galeri-galeri prestisius seperti Moma, Saatchi, dan lain-lain.

Karya-karya Stefan Sagmeister dikenal sebagai karya lithography dengan pendekatan sangat filosofis, kedalaman personal dan pembuatan tipografi dengan teknik manual menjadi ciri khas karya grafisnya .Ia membuat kalimat pada karya lithography dengan sangat cerdas. Karya Sagmeister yang paling terkenal adalah album cover artwork untuk band-band seperti The Rolling Stones, Talking Heads dan Lou Reed, dan untuk buku-buku, seperti Mariko Mori Wave UFO untuk Kunsthaus Bregenz.

Selain itu hal yang paling menarik dari proses kreatif ternyata tidak hanya dimiliki oleh kelompok seniman saja, seniman dalam bidang lain pun khususnya proses 
kreasi dalam hal menghasilkan karya visual, terdapat juga pada seorang desainer grafis, desainer produk, desainer interior dan seorang arsitek. Karena kelahiran paham tradisional modernisme yang mengklasifikasi high art dan below art, karya-karya yang dihasilkan dan proses kreasi seorang desainer tidak terlalu diperhatikan.

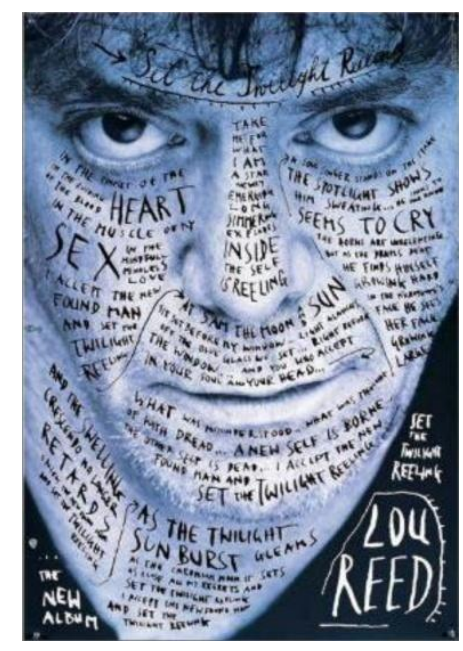

Gbr.I.1. "Set the Twilight Reeling”'Lou Reed poster, 1996

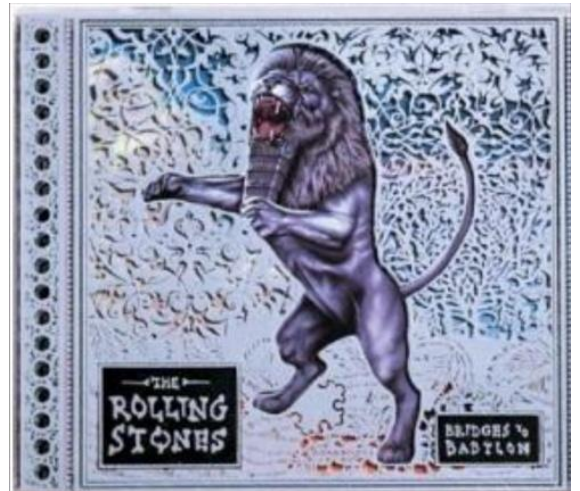

Gbr.I.2. “Bridges to Babylon”, Cd album Rolling Stone, 1997

\section{METODE DAN PEMBAHASAN}

Metode yang digunakan dalam penelitian ini menggunakan tiga Tipe Proses Kreasi dalam Psikologi Seni, yaitu;

\section{a. Discovering Problems (Penemuan Masalah)}

Penemuan masalah seperti halnya memecahkan masalah merupakan salah satu bagian yang dilakukan oleh seniman dalam proses penciptaan karya seni. 
Discovering problems (penemuan masalah) merupakan hal yang penting dalam proses kreasi. Kemampuan seorang seniman untuk menemukan masalah sebagai suatu tantangan merupakan potensi dari seniman yang sangat kreatif. Jacob Getzels dan Mihaly Csikszentmihalyi melakukan penelitian berskala besar tentang kepribadian dan kemampuan kognitif dan persepsi terhadap siswa seni, penelitiannya berdasarkan pada pandangan tentang motivasi manusia yang dikemukakan oleh para ahli psikologi yaitu ; Jean Piaget, Robert White, Hary Harlow, dan Daniel Berlyne, bahwa orang lebih sering termotivasi untuk meningkatkan tantangan daripada menguranginya. Teori ini berdasarkan salah satu bukti berupa fakta bahwa monyet mencari kegiatan-kegiatan yang menarik dan sering menghabiskan waktu luangnya dengan bermain puzzle daripada mencari-cari makanan (Harlow). Getzel dan Csikszentmihalyi berhipotesa bahwa orang kreatif adalah orang yang selalu mencari stimulus untuk termotivasi mencari dan menemukan masalah untuk diselesaikan.Mereka (Getzel dan Csikszentmihalyi) membuktikan hipotesis ini dengan percobaan terhadap sekelompok siswa seni untuk menggambar still life dari sekumpulan benda.Komponen penilaian dari hasil akhir gambar dinilai dari tiga komponen yaitu factor keaslian gagasan, kemampuan secara teknik dan factor estetis.Karya yang paling orisinal, dan bernilai estetis paling tinggi merupakan karya yang dihasilkan dari seorang yang suka mengeksplorasi dan menemukan masalah lalu memecahkannya sehingga menjadi karya seni yang baru.Berdasarkan fakta tersebut seorang seniman yang sangat kreatif selain dapat memecahkan masalah tetapi juga termotivasi untuk menemukan masalah baru untuk dipecahkan.

\section{b. Conscious Craft ( Keakhlian yang Disadari )}

Conscious craft merupakan salah satu tipe keakhlian / kemampuan yang dimiliki oleh seniman dalam melakukan proses kreativitasnya. Pada tipe ini seniman lebih menggunakan pemikiran logisnya sebagai proses utama berfikir dalam menghasilkan suatu karya seni. Teori conscious craft diungkapkan oleh tiga orang psikolog terkemuka yaitu, Rudolf Arnheim, David Perkins, dan Howard Gruber. Ketiga psikolog ini memiliki pendapat bahwa karya seni atau hasil kreasi yang diciptakan oleh seorang seniman bukan hanya sekedar memiliki keindahan secara 
visual tetapi juga merupakan hasil dari proses berfikir seniman dalam memecahkan suatu masalah. Conscious Craft merupakan kemampuan yang digunakan oleh seorang kreatif lebih pada keahlian yang disadarinya, atau dalam melakukan proses kreasi ia lebih menggunakan pemikiran rasional dan hasil pemahamannya akan sesuatu. Conscious Craft merupakan salah satu varian dari berbagai jenis proses kreasi yang digunakan oleh seorang seniman.

Pada proses conscious craft, seniman berpikir dan bekerja keras dalam memecahkan masalah, menggunakan pemikiran logisnya dlm menghasilkan karya seni, menggunakan kemampuan intelektual untuk memecahkan masalah, sehingga karya seninya bermutu secara intelektual, visual yang dihasilkan berdasarkan pertimbangan-pertimbangan yang logis sehingga dapat dijelaskan. Seniman melakukan banyak eksperimen untuk mencari pemecahan yang tepat dalam menggambarkan visinya.Dapat menggambarkan visi seniman keberbagai media ( multi media) yang sesuai dan media tersebut dapat selaras dengan visi seniman, memiliki tujuan dalam berkreasi, hasil karya merupakan pandangan seniman akan sesuatu hal, karya merupakan konsepsi seniman terhadap permasalahan yang ada dalam kehidupan, sehingga merefleksikan permasalahan kehidupan manusia, hal ini memperlihatkan kepedulian seniman yang disatu sisi mengangkat problematika kehidupan dalam karya seni merupakan usaha seniman dalam mengangkat realitas baik itu berupa kebenaran, kebaikan atau keburukan suatu kondisi masyarakat. Proses kreasi dengan tahapan-tahapan yang logis membuat kerja seniman lebih sistematis, jelas, dan terarah.

\section{c. The Creative Thought Process ( Proses Berpikir Kreatif)}

Bagaimana proses berpikir kreatif berlangsung dalam pikiran seorang seniman dan bagaimana seorang seniman berpikir selama melakukan proses kreatifnya, membuat ilmuan ingin mengetahui hal tersebut. Ada dua kecenderungan dalam proses berfikir kreatif, yaitu: 
1. Proses berpikir kreatif tak sadar

Dikemukakan oleh penyair Amy Lowell dan Max Ernst pelukis surealis. Mereka menyatakan proses kreasi yang dialami oleh mereka sepenuhnya tidak sadar, mereka berpendapat kemunculan gagasan hingga proses penciptaan karya seni merupakan proses yang sepenuhnya dialami oleh ketidaksadaran. Gagasan tiba-tiba muncul, lalu proses penciptaannyapun mengalir begitu saja secara intuitif.

2. Proses berpikir kreatif sadar

Dikemukakan oleh Edgar Allan Poe, seorang penulis.Ia berpendapat bahwa proses berpikir sepenuhnya dilakukan dengan kesadaran dan rasional dan sepenuhnya dilakukan berdasarkan perhitungan.

Namun sebagian besar ilmuan dan seniman menempatkan proses berpikir mereka di antara kedua hal tersebut. Mereka mengungkapkan adanya tahapan dalam proses kreasi, yaitu, mulai dari tahapan menemukan masalah, tahapan inkubasi atau pengeraman masalah, lalu tahapan pemecahan masalah. Richard agner, seorang composer, Jean Cocteau, seorang penulis naskah, dan Dorothy Canfield juga mendeskripsikan proses kreasinya pada proses kreasi ini.

\section{PEMBAHASAN}

\section{a. Proses Kreatif Stefan Sagmeister}

Tiga jenis proses kreasi yang kuat terdapat pada Stefan sagmeister, yaitu discovering problems, conscious craft, dan the creative though process, ditemukan dari karya desain dan pendapatnya tentang kreativitas. Hal tersebut sangat memungkinkan terjadi karena asumsi saya kecenderungan proses kreasi yang dilakukan oleh seorang seniman erat kaitannya dengan psikologis seniman tersebut. Dan Menurut saya seorang seniman memiliki ke sepuluh jenis proses kreasi tersebut dalam dirinya, ( Instinctual drive, ego strength, reinforcement, atypical thinking, intelligence, discovering problems, talent, creative thought 
process, unconscious incubation, dan conscious). Dimana kesepuluh proses kreasi tersebut merupakan kemampuan dasar yang dimiliki oleh seorang kreatif. Namun setiap orang memiliki salah satu dari kemampuan tersebut yang lebih dominan. Kecenderungan proses kreatif Stefan sagmeister sebagian besar didapatkan dari pemikiran dan pandangannya terhadap sesuatu yang tercermin pada karyakaryanya, maupun yang terdapat dari hasil wawancara.

\section{- Discovering problems sebagai Proses Kreatif}

Karya-karya Stefan Sagmeister yang sebagian besar menggunakan multi medium dengan rangkaian kalimat yang kuat dan penuh arti merupakan konseptual art karena ia memiliki konsepsi yang jernih yang ia tuangkan kedalam sebagian besar tipe karyanya yang berupa tipografi dengan pendekatan yang sangat personal dan sangat philosopis. Pada sebagian besar karya desain grafis yang dihasilkannya, berkaitan dengan bidang desain yang berbeda dengan bidang seni, dimana seorang desainer dituntut untuk mengkomunikasikan suatu pesan dari klien, tugas seorang desainer grafis adalah menemukan dan memecahkan masalah.dengan dua hal tersebut seorang desainer grafis harus menemukan solusi yang tepat untuk masalah tersebut, baik dari konsepsi, visual maupun mediumnya. Stefan sagmeister memiliki kecenderungan Discovering Problems dalam proses kreasinya. Hal ini terlihat jelas pada sebagian besar karya-karyanya yang sangat orisinal, karena pengaruh eksperimen yang selalu ia lakukan.

Berikut pemikiran Stefan sagmeister terhadap ide orisinil, yang mencerminkan bahwa ia merupakan seniman yang memiliki proses kreatif Discovering Problems;

"Make your own things,karena bila anda mengambil ide orang lain, ide itu tidak akan menjadi "baby" anda, ( ia menganalogikan ide orisinal dengan istilah "baby"), anda akan jadi baby sitternya saja. Anda tidak akan sepeduli, seantusias seperti bila ide itu adalah "baby" anda sendiri”.(Sagmeister, Stefan. Majalah concept, hal.66) 
Berikut penggalan wawancara dengan Emily Winifred Ford, mei 2008 yang mencerminkan Stefan sagmeister seniman yang memiliki proses kreatif Discovering Problems;

Ford: Your work is uniquely personal, you once scratched a lecture poster into your chest with a razor. Where does that desire come from?

Sagmeister: As a designer it's our job to communicate. I find that so much of communication falls into an old version of modernism: informed by machines, very exact, and ultimately cold. Although that kind of communication worked very well in the 20s and 30s when it was new-we've had it now 80 years, at least 40 of which it was the status quo-modernism now leaves a vast percentage of the audience pretty cold. So to bring in a personal point of view or even subjectivity seems to me like a pretty obvious strategy. I am not arguing that every piece of communication should be designed from a personal point of view, but even the type ofcommunication that seems the least conducive to personal communication would work much better were it not done in the standard modernism mode.

Fakta diatas memiliki tendensi yang kuat dari tipe proses kreasi discovering problem, dimana seorang seniman termotivasi untuk menemukan masalah baru untuk dipecahkan, menghasilkan keaslian gagasan dari penemuan dan pemecahan masalah tersebut, memiliki kemampuan secara teknik dan estetis. pada hasil wawancara dan pemikirannya tentang ide orisinil, Stefan sagmeister sangat setuju bahwa seorang yang kreatif haruslah menciptakan yang baru yang lahir dari pemikiran sendiri. Ia membuat gagasan baru yang keluar dari gagasan umum modernisme. Ia berani keluar dari faham main stream dan membuat karya yang sangat berbeda, mengejutkan, inovatif, propokatif.

\section{- Conscious Craft sebagai Proses Kreatif}

Stefan Sagmeister merupakan desainer grafis yang memiliki proses kreasi yang logis. Ia banyak sekali menuangkan pemikiran piloshopisnya kedalam 
karya grafisnya. Ia menggunakan kemampuan intelektualnya untuk memecahkan masalah. Visual pada karyanya sebagian besar berupa kalimat pilosopi yang dalam dan sangat personal, dengan penggunaan typhography, merupakan hasil dari pertimbangan- pertimbangan yang logis sehingga dapat dijelaskan.ia melakukan banyak eksperimen untuk mencari pemecahan yang tepat dalam menggambarkan visinya. Secara periodik, ia menutup pekerjaannya membuat pesanan desain untuk klien, selama setahun penuh Ia mendedikasikan waktu khusus untuk melakukan eksperimen pribadi. Hal ini dilakukannya agar gagasan dan kreatifitasnya tetap segar dan juga ia melakukan eksperimen untuk mengasah gagasannya yang ia pikirkan secara matang. Ia menuangkan gagasannya keberbagai media, agar selaras dengan visinya. Sag meister selalu memiliki tujuan dalam berkreasi, hasil karyanya merupakan pandangan akan sesuatu hal, karyanya merupakan konsepsi terhadap permasalahan dalam kehidupan manusia, hal ini terlihat jelas pada diri sagmeister karena menurutnya berkarya merupakan "personal point of view".

Ia memiliki proses kreasi sangat sistematis. Dimana ia memiliki jadwal rutinitas untuk kegiatannya sehari-hari. Mengatur waktu secara sistematis dan bekerja dengan disiplin menurutnya dapat membantu bekerja/berkarya lebih efektif dan dapat dinikmati. Hal tersebut menegaskan bahwa ia merupakan salah seorang kreator yang memiliki kecenderungan conscious craft dalam proses kreasinya. Berikut pemikiran Stefan Sagmeister yang mencerminkan bahwa ia merupakan seniman yang memiliki proses kreatif conscious craft;

\section{"Self confidence Produces Fine Results"}

"If I Want To Explore A New Direction Professionally, It Is Helpful To Try It Out For Myself First"

"Things I Have Learned In My Life So Far"

"Trying To Look Good Limits My Life"

"Design that needed guts from the creator and still carries the ghost of these guts in the final execution." 


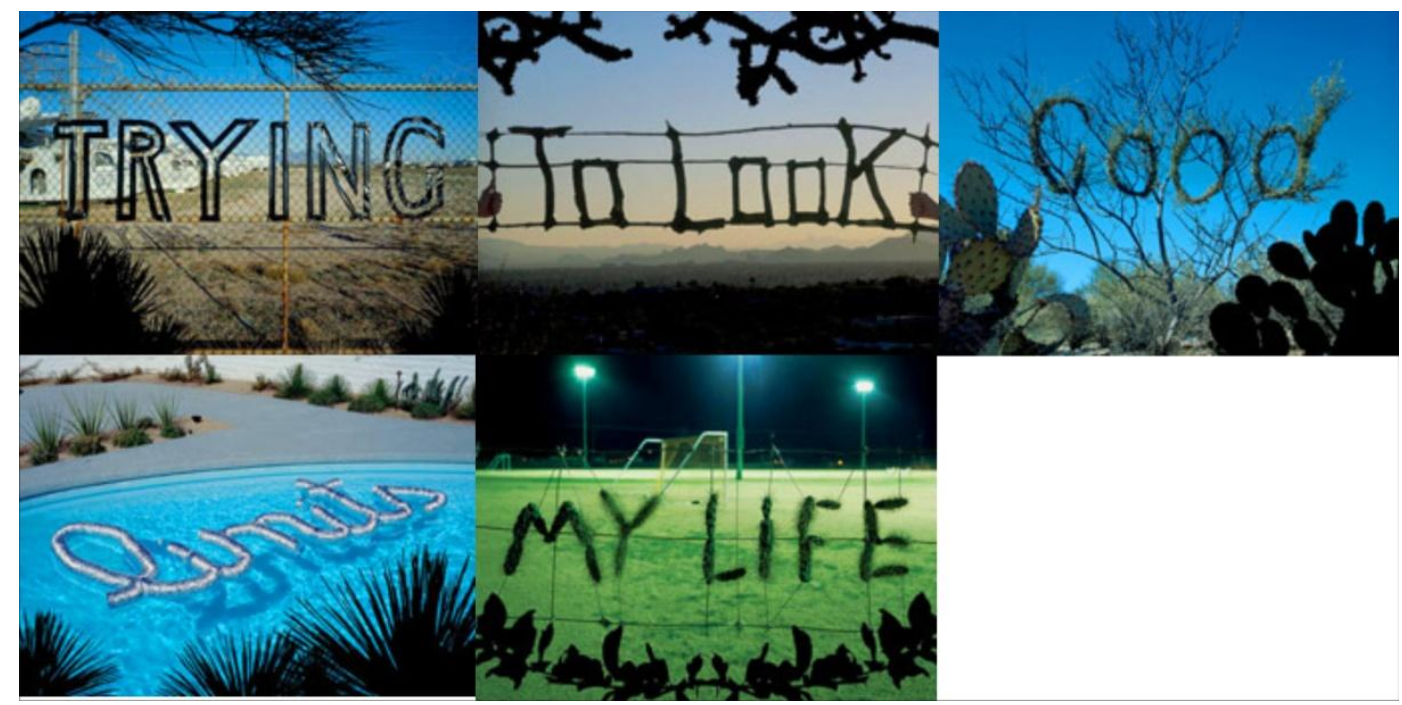

Gbr.III.5. “ Trying To look good limits my life” Things I learned in my life so far series project, 2008.

Berikut penggalan wawancara dengan Emily Winifred Ford, mei 2008 yang mencerminkan Stefan sagmeister seniman yang memiliki proses kreatif conscious craft:

Ford: Your work is uniquely personal, you once scratched a lecture poster into your chest with a razor. Where does that desire come from?

Sagmeiter: As a designer it's our job to communicate. I find that so much of communication falls into an old version of modernism: informed by machines, very exact, and ultimately cold. Although that kind of communication worked very well in the 20s and 30s when it was new-we've had it now 80 years, at least 40 of which it was the status quo-modernism now leaves a vast percentage of the audience pretty cold. So to bring in a personal point of view or even subjectivity seems to me like a pretty obvious strategy. I am not arguing that every piece of communication should be designed from a personal point of view, but even the type of communication that seems the least conducive to personal communication would work much better were it not done in the standard modernism mode.

Ford: What are your plans for your upcoming experiment year? 
Sagmeister: I have a long list, which I wrote down in the last year or two, which needs to be ordered by importance and assigned weekly hours. I found that if I don't make a plan, others will make it for me. In my previous clientfree year, my initial intent of just seeing what comes didn't work at all because my time was filled up with students from Korea asking questions or a Japanese design magazine wanting files to be sent, etc.

Ford: When do you use time constraints in your everyday work?

Sagmeister: When it comes to idea generation I find it particularly helpful to have little pockets of designated time when you say, "I'm going to think about this now for 15 minutes." And in those 15 minutes you're truly thinking about it rather than going to the loo or checking email or doing something else. When I returned to my regular studio mode following the experimental year, I tried using constraints again for regular client work. For example, in designing the billboard "Trying To Look Good Limits My Life" for Paris I used this same technique. We said, "Okay, let's take five days. We'll have one day for every billboard. We'll start at sunrise and we will have to be done at sundown because we don't have any flash equipment." This significantly changed the outcome both in concept and in form.

Ford: How did the time constraint in the CD cover inform the design?

Sagmeister: I think constraints are good in general. Limited freedom is a very difficult place to work in. Brian Eno, who now is a client, once said the electric guitar became the predominant instrument of the 20th century exactly because it is such a "stupid" instrument, because it can do fairly little. The synthesizer, in contrast, never quite took that dominant place because the things it can do are too vast. And I think that, within that same realm, as a designer, you can take on various constraints. One of the constraints I took on in that year was time constraints. Designing a CD cover within three hours utterly changed the nature of the outcome. I had to work with existing materials. You don't have the luxury, the possibility, or the difficulty to say, 
"Okay this would work really great if had this computer program or that material right now." You have to make it work with the stuff you have. Of course this significantly changes the outcome not only in form but also conceptually since there was little time to conceptualize the whole thing. So the CD covers took in, and were informed by, my own little anxieties and inabilities. Because the process is so immediate-ideas need to take shape right then-I find that the results are automatically more personal pieces as a result. I think in the experimental year specifically, because it was an artificial time constraint - the outcome didn't need to be printable-it was very exciting to work this way.

Ford: Is there something in addition to the literal meaning of the maxims that you were trying to communicate?

Sagmeister: In many of them we pursued a strategy for the form that did not necessary come out of the saying itself. I thought that otherwise I might create a very one-dimensional saying that people would have difficulty finding themselves in. Instead, I created forms for many of them that have meaning to me but are opaque to an outside viewer. For example "Everything I Do Always Comes Back to Me" is made of onion rings which is a reference to my mentor Tibor Kalman's onion ring collection. The regular viewer somewhere in Korea or France wouldn't know that of course. But, because the saying itself is so straight forward, without irony, the more opaque form opens up the possibilityfor interpretation for the viewer. I felt that was going to happen and I found evidence that this in fact did happen with a number of pieces. 

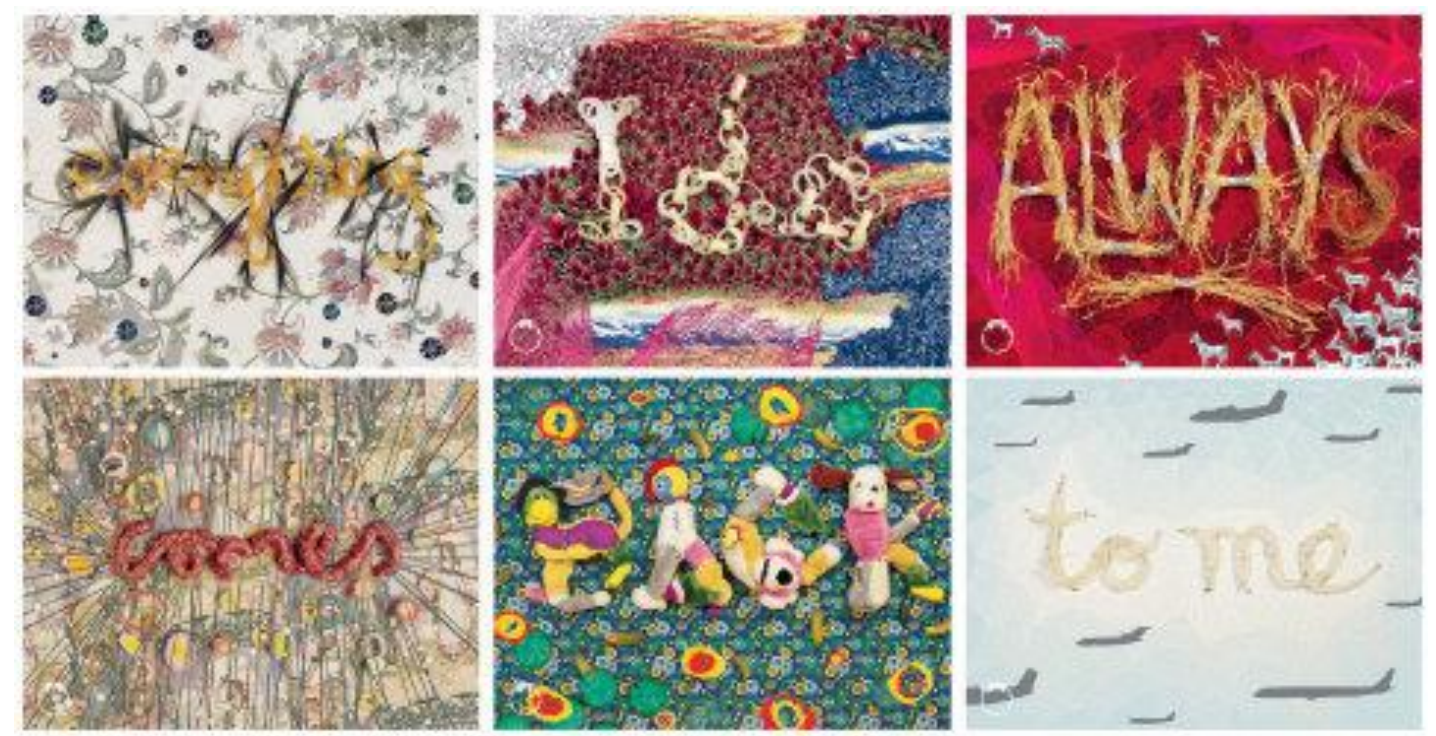

Gbr.III.6. "Everything I do Always Comes Back to Me"

\section{- The Creative Thought Process sebagai Proses Kreatif}

Masih berkaitan dengan 1 tahun eksperimentalnya, ia menggunakan tahun tersebut untuk melakukan eksperimen, melakukan pencarian dan penemuan ide baru, proses tersebut merupakan tahapan proses kreasi yang dimiliki oleh sagmeister. Tahapan proses kreasinya ia lakukan secara periodik. 1 tahun dari per-tujuh tahun sekali, ia gunakan sepenuhnya untuk melakukan tahapan proses kreasi. Hal tersebut menurutnya sangat penting bagi seorang desainer ataupun seniman.Keluar dari rutinitas sehari-hari untuk menyegarkan kreatifitas. 1 tahun eksperimental tersebut ia gunakan untuk mencari ide baru, memindahkannya kedalam buku sketsa lalu berpindah ke ide yang lain. Pada tahun 2008, ia melakukan tahun eksperimentalnya di Bali, Indonesia. Tahun eksperimental tersebut ia gunakan tidak hanya untuk mencari ide-ide baru tetapi sekaligus bereksplorasi dengan ide tersebut, mengeksekusi ide dengan mencoba media-media yang baru. Hal ini menunjukkan bahwa Stefan sagmeister juga memiliki proses berfikir kreatif (the creative thought process) dalam proses kreasinya.

Berikut pemikiran Sagmeister terhadap proses kreasi: 
"melakukan eksperimen sepanjang hidup adalah lebih baik daripada melakukan eksperimen di akhir hidup”. (Sagmeister, Stefan. Majalah concept, hal.62)

Berikut penggalan wawancara dengan Emily Winifred Ford, mei 2008 yang mencerminkan Stefan sagmeister seniman yang memiliki proses kreatif the creative thought process:

Ford: Your approach to experimenting is different from most design houses, which take an hour at the end of the day for experimentation. To have a whole year is very different.

Sagmeister: I think ultimately its very similar. If you're a designer desiring experimentation, you will have to institutionalize it. If you don't, you won't experiment because jobs with deadlines will always take precedence. Whether it is an hour every day, or a week every month, or a year every seven years, I think ultimately that's just a matter of timing.

Hasil penggalan wawancara dengan Lou Reed, September 1995, sebagai berikut:

Lou Reed: Why did you take time off?

Sagmeister: For one thing, the work was becoming repetitive. We were starting to redo ideas we had done before, and in retrospect, having worked in many different cities, I was missing this gap in between that allows for reorientation. I also had led a workshop at Cranbrook where these mature students created a two-year space for themselves just for free-thinking experimentation, and I got really jealous. So I told all my clients a year in advance I would be taking a year off.

Lou Reed: So what was on the top of your list?

Sagmeister: The objective was not to end up with completed projects, but to experiment. At the very beginning, every possibility was open, maybe I'd go 
into film or music. I dropped both of these paths very quickly, realizing that it would take 10 years to learn to the point where I could speak these new languages. I decided it would be more productive to use the language of graphic design Iknow and spend my time figuring out if I have anything else to say. Aside from experimenting, one of the challenges I had given myself was to try to think BIG, BIGGER, always in bigger terms. I also started to seriously rethink the direction of the studio from an entertainment-- related studio towards socially-conscious assignments.

\section{b. Tinjauan Karya Stefan Sagmeister}

Karya desain yang dihasilkan oleh Stefan Sagmeister memperlihatkan tiga tipe Proses Kreasi yang telah di bahas pada sub bab sebelumnya, yaitu Conscious Craft, Discovering problems dan The Creative Thought Process sebagai Proses Kreatif yang dimiliki. Cirri-ciri tersebut dapat terlihat dengan jelas lewat karyakarya berikut ini;



Gbr.III.7. Poster untuk AIGA “Fresh Dialogue Talks” di New York,1996 


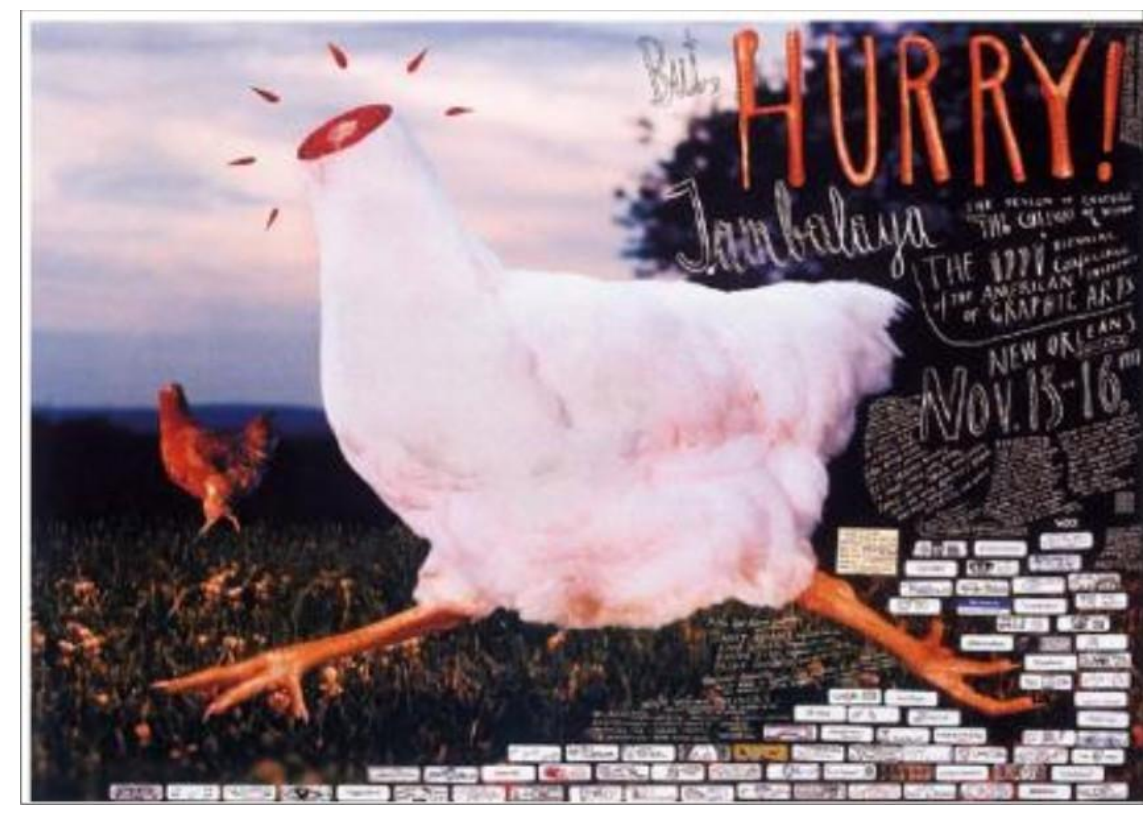

Gbr.III.8. Poster untuk Biennial Conference di New Orleans, 1997



Gbr.III.9. “AIGA Detroit”, Poster untuk AIGA (American Institutional Graphich Art), 1999. 

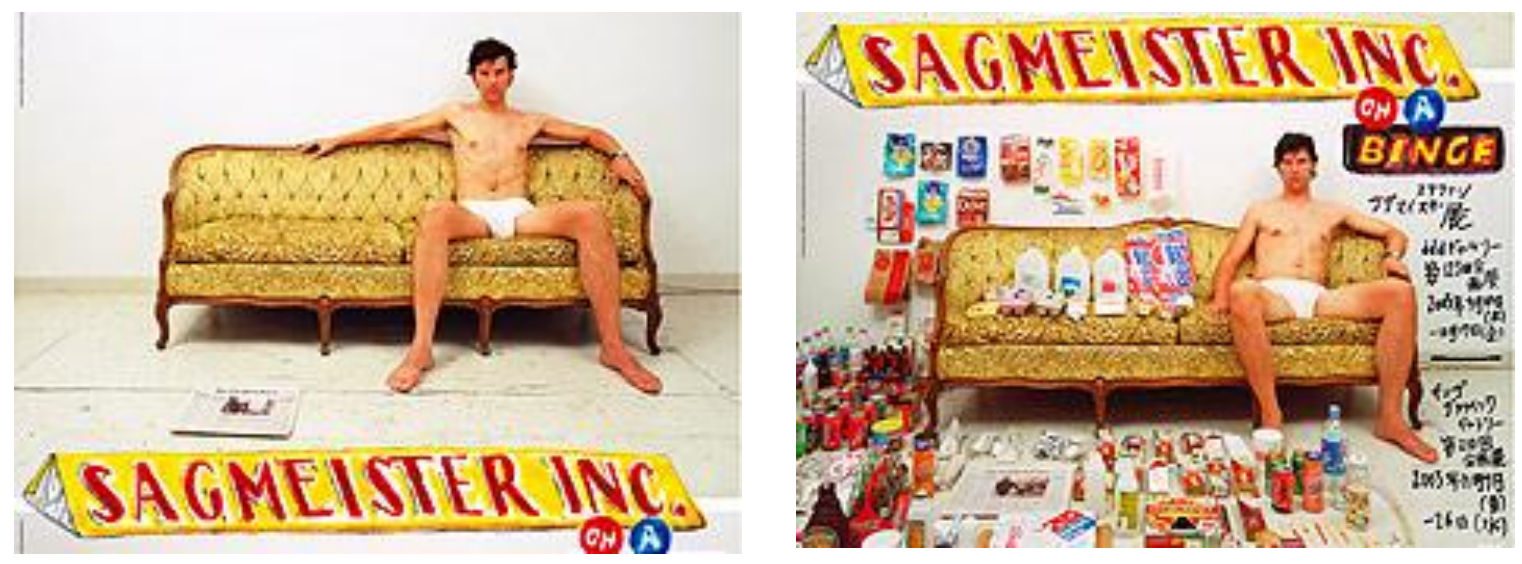

Gbr.III.10. Poster Jepang, untuk GGG gallery.

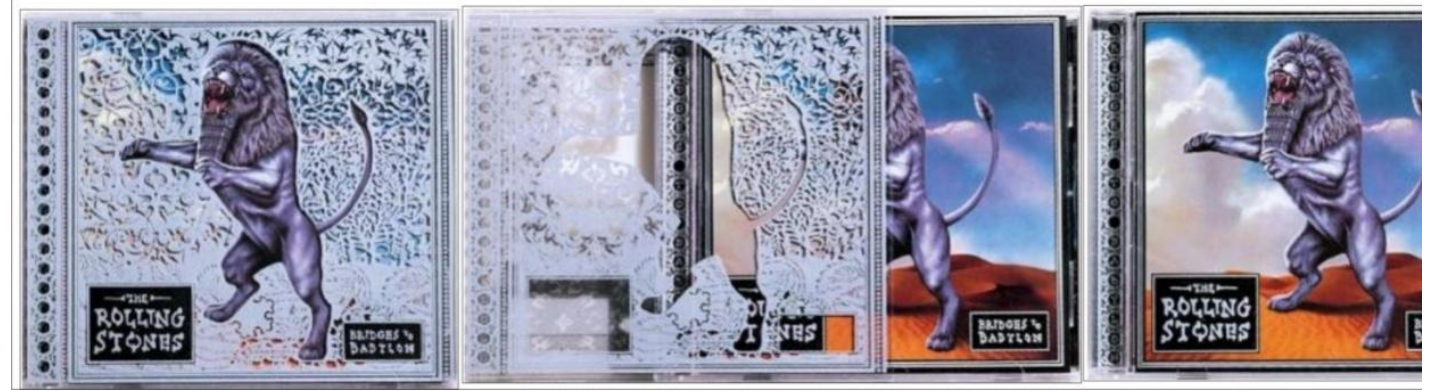

Gbr.III.11. “Bridges to Babylon”, Cd album Rolling Stone, 1997

Program Studi Desain Komunikasi Visual, Universitas Komputer Indonesia 


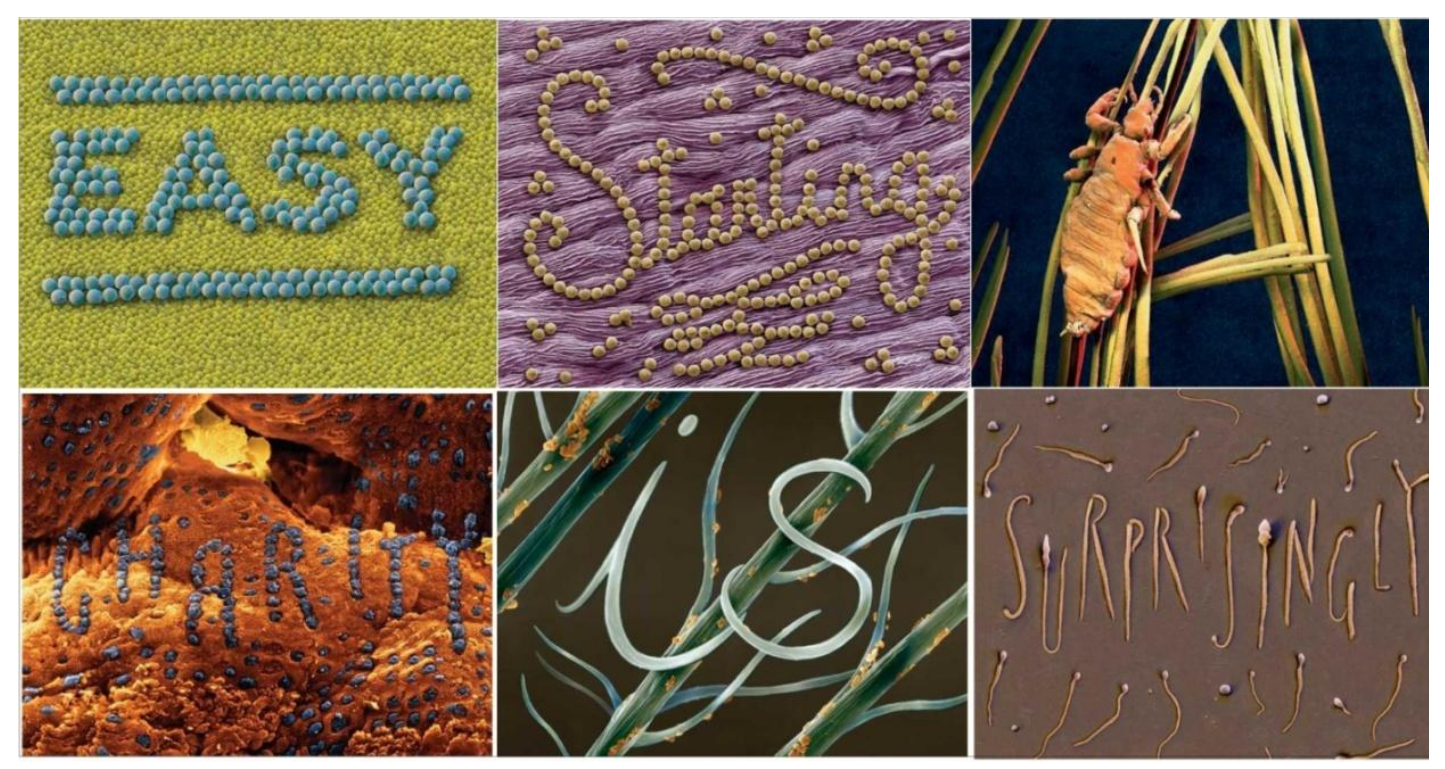

Gbr.III.12. " Easy Starting A Charity Is Surprising”

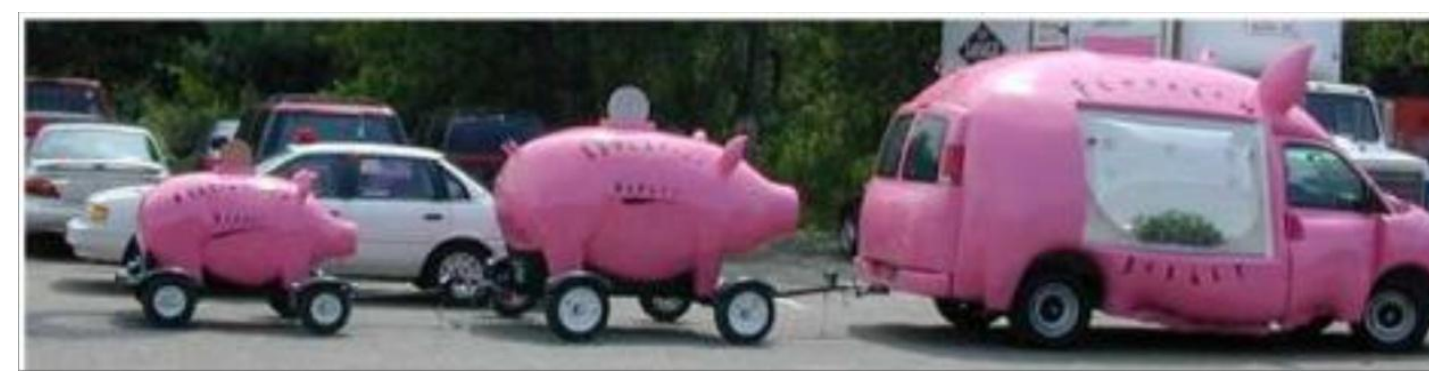

Gbr.III.13. “True Majority”, proyek yang dibuat untuk kampanye agar pemerintahan Amerika memotong 15\% anggaran dari pentagon untuk dialokasikan kepada pendidikan. 

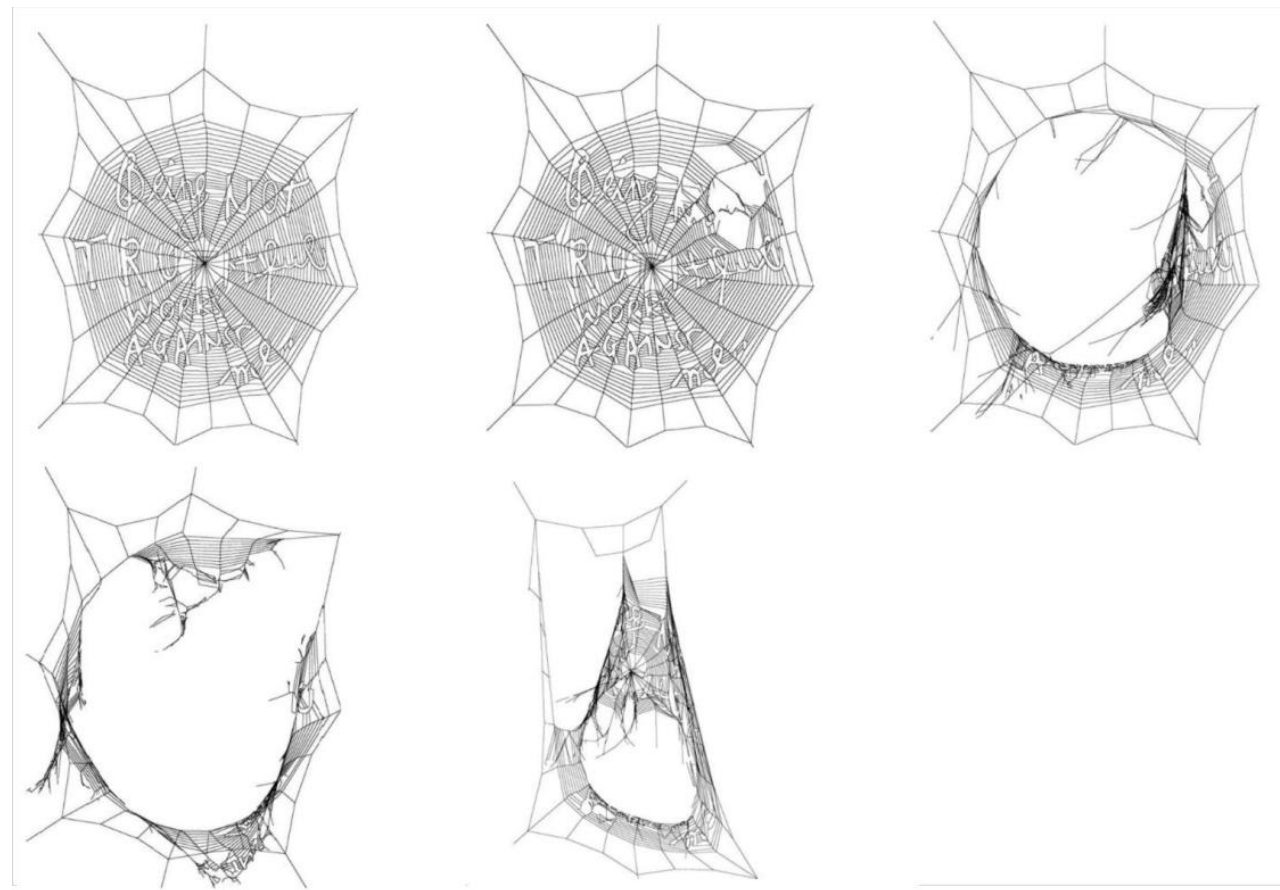

Gbr.III.14. "Being not Truthful Works Against Me”, 2006. sebuah karya instalasi berupa proyeksi interaktif dibuat untuk Austrian Cultural Forum di New York
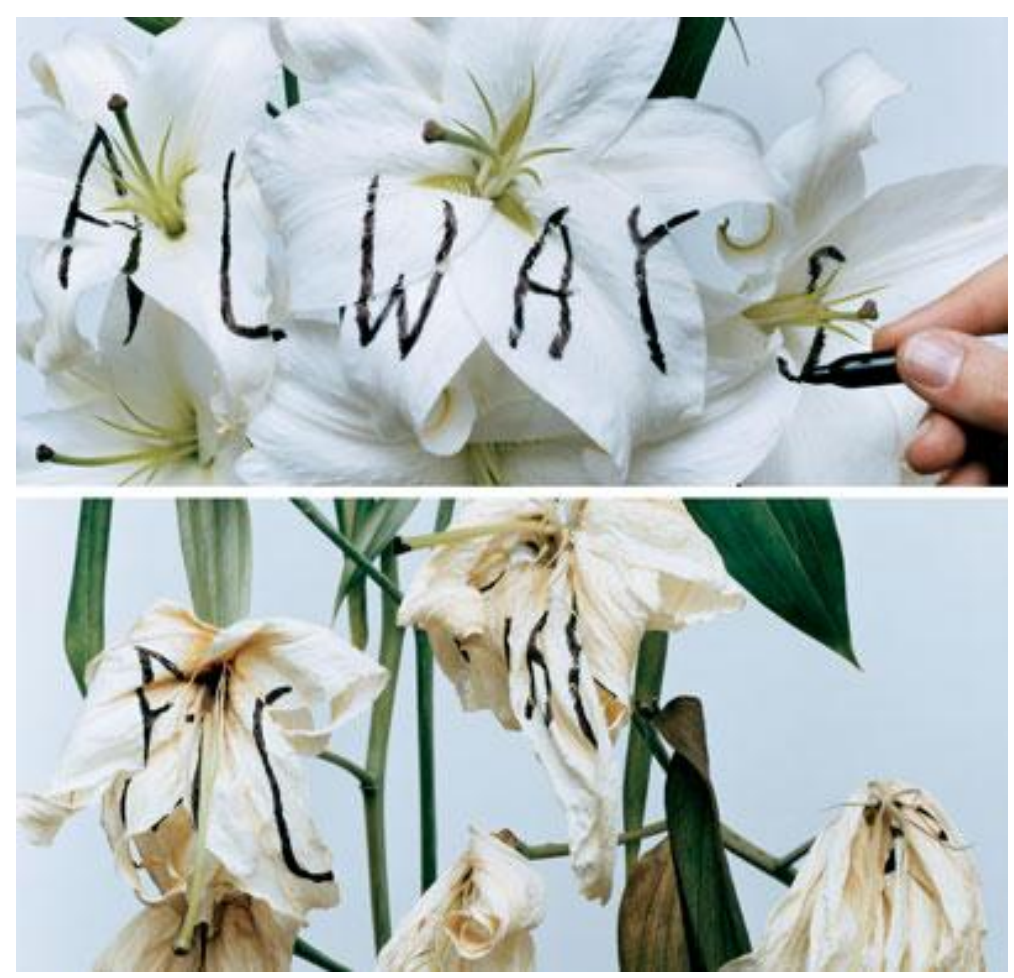

Gbr.III.15. "Always"

Program Studi Desain Komunikasi Visual, Universitas Komputer Indonesia 


\section{KESIMPULAN}

Stefan Sagmeister seorang seniman yang hidup dan berkembang diwilayah desainer grafis, meskipun demikian ia merupakan seorang seniman yang memiliki pandangan terhadap kehidupan yang ia citrakan lewat karya-karya grafisnya dengan social responsibility dan muatan phylosopis yang kuat. Konsepsi yang dalam dengan gaya grafis yang banal, humor, eklektik, hybrid, menjadikan ia seorang desainer grafis masa kini yang terkenal dan berpengaruh.

Ia menekankan bahwa membuat karya dengan menitik beratkan pada tujuan yang mulia, lewat kalimat yang memiliki arti bagi masyarakat, dapat menularkan penyadaran dan kepedulian. Sehingga hal tersebut dapat memperbaiki kualitas kehidupan secara global.Menurutnya desainer grafis tidak hanya melulu bicara persoalan iklan dan bagaimana menghasilkan uang dari pekerjaan tersebut.Tapi desainer grafis juga harus menjadikan karyanya sebagai media penyadaran moral dan spiritual.

Berkaitan dengan proses kreasi yang ia lakukan, dengan 1 tahun eksperimental sebagai media meditasi bagi proses kreasinya, mengutamakan kejernihan berpikir, kesegaran ide dan kreatifitas, menjadikan karya-karyanya selalu mengejutkan dan menggairahkan,. Cerdas lewat sederetan kalimat yang mempropokasi masyarakat untuk memikirkan lebih dalam makna yang terkandung didalam karya-karya grafisnya.Proses kreasi yang ia miliki apabila kita lihat dari sisi teori, ia memiliki tiga jenis proses kreasi yaitu discovering problem, Concious craft dan the creative thought process, ketiga proses tersebut sangat menonjol pada diri Stefan Sagmeister. 


\section{DAFTAR PUSTAKA}

Damajanti, Irma. 2006. Psikologi Seni. Kiblat.

Hartanto, Djoko. "The Year to Live Experiment" .Artikel majalah desain grafis 'Concept'.Hal 58-66, Vol 05 edisi 26, 2008.

http://www.ambidextrousmag.org/issues/10/sagmeister.html Interview with Stefan Sagmeister, byEmily Winifred Ford, May 2008. Diunduh pada tanggal 13/05/2010.

http://www.deitch.com/projects/sub.php?projId=230.Diunduh pada tanggal 13/05/2010.

http://www.designmuseum Collection.com. Stefan Sagmeister Graphic Designer (1962-). . Diunduh pada tanggal 12/05/2010.

http://www.findarticles.com/p/articles/mi_qa3992/is_200205/ai_n9028790/_In conversation with Stefan Sagmeister and Lou Reed: Take a Walk on the Wild Side. Diunduh pada tanggal 13/05/2010.

http://www.moma.org . Rough Cut, Design Takes a Sharp Edge. Diunduh pada tanggal 12/05/2010.

http://pingmag.jp/2005/09/27/visiting-stefan-sagmeister/Visiting Stefan Sagmeister Interview by Uleshka. Diunduh pada tanggal 13/05/2010.

http://www.wikipedia.com. Stefan sagmeister.Diunduh pada tanggal 12/05/2010. 